\title{
Viewpoints
}

NRF, A United Nations Sustainable Development Journal is running a special series over the 2009-2011 period on themes to be considered by the UN Commission on Sustainable Development in its $18^{\text {th }}$ and $19^{\text {th }}$ sessions: chemicals, mining, sustainable consumption and production, transport, and waste management. In this issue, experts address the question:

\section{"How can revenues from natural resources extraction be more efficiently utilized for local sustainable development?"}

Implied in the question is an 'agency' that is in charge of receiving and, in turn, 'utilizing' the revenues for the local communities. In this formulation, the communities inhabiting the local geographical scale are seen as being 'acted upon' by this higher body; good is being done to them. This innocuous question, therefore, consolidates the undulating terrain of power before a dialogue can begin on a level-playing field.

The question needs to be changed to: 'how can local communities utilise the natural resources to achieve sustainable developmental outcomes?' Such a formulation would not embed rent-seeking by extractive companies multinational or nationally owned - and the State. The local communities would not be stripped of ownership of resources, which happened historically during colonization often through enclosure.

If I had to give a prescription a la 'What is to be done', I would advocate that mineral resources be co-managed with only a small portion of the revenues given to the national and other state agencies. In a number of other natural resources sectors, the local communities' ownership, interest and ability to manage have been recognised. Evidence is mounting that co-management yields more equitable and sustainable developmental outcomes. Imagining an alternative (and better) future would involve radically changing the current power superstructures, and a first step is to accept the local communities as rightful owners of resources and as resourceful enough to manage the revenues for themselves.

Kuntala Lahiri-Dutt Fellow, Resource Management in Asia Pacific Program The Australian National University Australia

Effectively utilizing resource revenues begins with empowering communities to meaningfully participate in decision-making. As the intended beneficiaries of revenue redistribution and (too often) the victims of the negative impacts of extraction, communities have a right to a voice in determining when and where resource extraction will occur, and how it will support existing livelihoods. Local laws and corporate policies should be reformed to enable this. Communities also have a right to information on resource revenues, environmental impacts, and local budgets. Community groups should receive the training and technical support needed to act on this information. Governments should allocate resource revenues for this purpose.

Extraction creates few jobs and thus little direct local economic benefit. Benefits must come via investing revenues in, for example, agricultural production or valueadding industries. Governments should explain how these investments fit into national development strategies, including infrastructure development and economic diversification, so that they do not become isolated enclaves. Recent experiences in Peru, Chad and Papua New Guinea demonstrate that resource-based growth does not magically "trickle down". A mine or pipeline may bring clinics or schools. But if the revenues they produce do not increase productivity and employment, they do not contribute to broad-based development.

Keith Slack Extractive Industries Program Manager Oxfam America Washington, $D C$

A major impediment to increasing local sustainable development benefits from the extraction of natural and mineral resources is that agreements made between companies and governments do not take into account the needs of local populations and their use of the area. Postmining phase work and land-use should be planned at the 
conception of the extraction activity. Planning across landscapes to consider the various uses and needs met by natural resources would help to account for an equitable division of resources. In addition, training indigenous government geologists to be better able to negotiate mining leases could ensure that sustainable development is more efficiently safeguarded. Providing relevant educational opportunities in the earth sciences that are regionally sited, use appropriate local data, and focus on solving regional issues could help guarantee local benefits are obtained. The private sector must engage with universities and geological surveys in order to accomplish this mutually beneficial transfer of skills, knowledge, and material wealth to provide a well-trained local staff.

\section{Secretariat of the IGCP Programme UNESCO}

Paris, France

Although the question about how to use revenue from natural resource extraction is a valid one, a more pressing question has often been if such extraction is actually desired by or desirable for local communities. All too frequently, concessions for natural resource extraction are made without due deference to the rights and interests of indigenous and other local people to their traditionally occupied territory and to free, prior and informed consent. These rights are widely recognized and were recently reinforced by the Inter-American Court of Human Rights, which noted that 'members of tribal and indigenous communities have the right to own the natural resources they have traditionally used. Without them, the very physical and cultural survival of such peoples is at stake' and 'when large-scale development or investment projects could affect the integrity of [such] people's lands and natural resources, the State has a duty to obtain their free, prior, and informed consent.' It is vital to remember that a key element of local sustainable development is ensuring that the rights and interests of indigenous peoples and other local communities are recognized and respected by states and companies; this means that resource extraction may not be the preferred route to local development in the first place.

\section{Lauren Baker \\ Doctoral Student Yale School of Forestry and Environmental Studies New Haven, Connecticut}

Local enterprise development needs to be an integral part of societal capacity building for local sustainable development. This enterprise development - the building of capacity among local people to provide products and services that support broader sustainable development efforts - can substitute for seed finance and aid in developing countries. The sustainable extraction of natural resources - timber, ore, precious gemstones, other minerals, water, fossil fuels - must be viewed as a multistakeholder, multi-level capacity building venture. The only way to answer the question in any given context is to create a tailored participatory assessment, planning, implementation and monitoring process that considers how alternative extraction plans (including their supportive capacity building) will yield local benefits, and how the positive and negative impacts will be distributed among stakeholders. So, in practice the answer is context-specific. But in general, we can put in place the necessary multistakeholder processes - the social enterprise architecture if you will - that makes informed choices possible. Development agencies, NGOs and governments (central and local) should be supporting the creation of social networks that bring diverse social actors together to understand baseline conditions and needs, and compare natural resource development alternatives in ways that reveal their anticipated social, economic, cultural and ecological impacts.

Dr. Timothy J. Downs Environmental Science \& Policy Program, Dept. of International Development, Community \& Environment, George Perkins Marsh Research Institute Worcester, Massachusetts

The best answer is very simple:

"Ensure that local communities are in a position to earn revenues from natural resources extraction. This may require that local communities be given ownership, or at least participation, in natural resources extraction on land they consider to be their own."

Jeffrey A. McNeely Chief Scientist

International Union for Conservation of Nature (IUCN)

Gland, Switzerland

Local sustainable development has two interrelated sides, environmental and economic. Revenues from natural resources (NRs) extraction can be efficiently utilized for local sustainable development both directly and indirectly. From the environmental perspective, a direct approach is a government rule that requires all companies performing NRs extraction activities to use part of their revenues for financing "NRs friendly" activities, e.g. forest management and maintenance, water treatment, development of better technologies/ways of production to reduce $\mathrm{CO} 2$ emissions. An indirect approach is for the companies to pay an extra tax or retribution to be used by the local governments to finance such 'NRs friendly' activities. From the economic perspective, a direct approach is to require the companies to 
employ local people and use local inputs. It also includes production linkages (e.g. subcontracting arrangements) with local firms in other sectors e.g. transportation, services, manufacturing. An indirect approach is through local community development programs, e.g. infrastructure development, building schools, funding study grants for local youth, etc. Rather than local communities being dependent on extractive companies, such programs should promote communities that are independent economically andtechnologically, so that when NRs extraction activities are ended, the local economic development does not collapse.

Prof. Tulus Tambunan

Center for Industry, SME \& Business Competition Studies

University of Trisakti Jakarta, Indonesia

In developing countries, natural resources are often managed solely for revenue generation. Natural resource revenues may contribute to the national exchequer but diminish local development. To improve this situation, different approaches such as development of markets, payments for ecosystem services, and community based adaptive management have been developed. These approaches provide alternative frameworks to select development paths, alas often ignoring the costs associated with them.

These frameworks could be strengthened by using the 'marginality' concept, which reflects changes in value (costs or benefits) due to change in one unit resource. Firstly, not all sections of the community are equally dependent on natural resources. Therefore they respond differently to changes in natural resources. Secondly, not all natural resources services are equally important to the local community. In summary, different services of natural resources have different levels of marginal benefits and costs to different sections of the community, which, in turn, are likely to have different kinds of needs and capabilities to respond to changes.

Consequently, to ensure efficient long-term development, the planning frameworks should take account of the marginal costs and benefits for different sections of the community over different timeframes, and use revenues accordingly.

\section{S. Iftekhar School of Agricultural and Resource Economics University of Western Australia Crawley, Australia}

One obvious, but in practice often overlooked, means is through meaningful public participation. The aim might not be to use revenues more efficiently but to invest them more collaboratively and equitably. Not all social investments lead to positive outcomes. Actions, even well-meaning ones, which are not socially, culturally, or environmentally grounded in the people and places (potentially) affected by a development, invariably result in poor outcomes.

Investment of revenues derived from taxation or royalties, and direct investment by resource developers (e.g. community trusts, foundations and community development programs), can both benefit from varying degrees of (local) public involvement. Participation can shape proposals, influence decision making, build trust, legitimacy, and capacities. Participation can range from community boards and reference panels, the submission of ideas for, and implementation of, community projects, devolved decision making, provision of consent, and innovative exercises such as community visioning processes to guide investments. In areas of intense resource development cooperation can target cumulative impacts.

Understanding communities, their relationships, networks, world views, how people construct what is a resource, and the customs that guide how they relate to them are important first steps. But, ultimately, the answer is that government and resource developers (and especially academics!) do not have all the answers. Through participation they may open meaningful dialogue, address real and perceived community concerns, and negotiate mutually beneficial futures that are more sustainable and locally relevant.

\section{Dr. Daniel Franks \\ Centre for Social Responsibility in Mining Sustainable Minerals Institute The University of Queensland Brisbane, Australia}

In the Brazilian Amazon region reality, revenues from natural resources extraction come from the income earned by local communities through the sale of forest products, mostly lumber, essences, fishery and hunting. To equate these income flows to a sustainable development framework, which by definition, meets the needs of the present without compromising the ability of future generations to meet their own needs, a balance must be found between present and future consumption, involving a trade-off between diminishing and increasing the existing stock of natural resources.

This could be accomplished primarily through two main vectors: market integration and education. Revenues generated locally must be invested in expanding market integration by, for example, creating an added-value system for certified sustainable products. This would generate economic incentives for locals to establish balanced production processes of forest products.

On the other hand, education should instil the significance of the rain forest as the locals' main asset; an 
asset that must be preserved for future generations as well as for continuous income-generating activities. Both of these courses of action should aid a better allocation of locally-generated revenues, resulting in a healthier equilibrium.

Prof. Waldemar Souza Federal University of Amazonas - UFAM Manaus Amazonas, Brazil

The challenge of making revenues from natural resources extraction benefit sustainable local development is resolute; requiring multi-pronged approaches to resolve. This problem is more pronounced in developing countries where economic development relies primarily on extractive industries, such as mining, petroleum, fishing, trophy hunting and timber exploitation. While attempts are being made to optimize revenue retention for local sustainable development, compliance by the multi-national, private and state-owned extractive companies in disclosing payments (royalties, fees, taxes, etc) made to the governments is still unsatisfactory.

Greater transparency would promote accountability for these revenues, reducing corruption and expropriation of national resources by individuals. Success requires:

- The governments of nations with extractable resources should implement policies, legislation and procedures that enable transparency. The civil society should support this legislation by advocating for and mobilizing public support for transparency.

- Greater rural communities' participation in decisionmaking on resource revenue distribution. This would require well capacitated and informed grassroots' governance institutions that are able to demand and advocate for broad-based economic and social development of their constituencies.

- Donor organizations should financially support the empowerment and capacity building of civil society organizations across resource-rich countries so that they can take the lead in mobilizing citizens to hold their governments accountable for the management and expenditure of revenues received from extractive industries.

- Social and environmental certification of extractive industries by independent agencies to ensure that both renewable and non-renewable resources are exploited in a manner that ensures social and environmental safeguards, as well as contributing to socially responsible local development.
Many governments, national and international stakeholders, scientists and several others interested in environmental issues are realizing the important role local communities, local landowners and local stakeholders play in natural resource conservation. One way to engage those stakeholders is to allocate a portion of the revenues accruing from natural resource exploitation to local developmental issues. However, the exact mechanisms that allow the efficient utilization of such revenues at the local level are not always well understood.

To ensure efficiency in revenue utilization at the local level and the derivation of long-term benefits from the investment it is important to devote time and effort to understanding several crucial realities of local environments and: 1) clearly identify the scope, breadth and interest of local, national and international stakeholders that affect local development issues; 2) have a good understanding of local development needs and priorities directly from local communities, local institutions and local key individuals; 3 ) ensure there are appropriate structures and mechanisms to monitor revenue utilization; 4) clearly understand the factors, mechanisms and forces that connect local economies to the greater national and international economies; 5) integrate development efforts to existing development structures and institutions; and most important, 6) have a good understanding of the history, culture, and social structure of local people and how they relate to their environment.

\section{Dr. Oscar Wambuguh Assistant Professor Environmental Health Sciences California State University, East Bay Hayward, California}

The conventional practice where natural resource monitoring responsibilities are shifted to the grassroots but the net incomes accruing from the resources (e.g. timber, gold, cacao, and oil) are controlled at the formal governance sectors is inimical to maximising revenues. This alienates ownership, and spawns violent civil conflicts, which potentially curtail initiatives to sustain local development. Thus, for revenue utilization to generate sustainable gains that significantly surpass the marginal efficiency threshold will require fresh policies and adaptable legal strategies that encourage participatory conditionality and rigorous financial accountability amongst local authorities, legitimate civil societies and global governing institutions not only during resource management but also at negotiated points of sharing natural resource wealth.

Sylvanus S. P. Doe

Simon M. Munthali African Wildlife Foundation Johannesburg, South Africa Sustainable Development Researcher \& Consultant
UCC-OCIC Partnership Programmes
Accra, Ghana 
Revenues from natural resources extraction are always the focus of some serious and sometimes passionate debates in the press, but seldom in the localities where they are originated. This is even true for cases when, by law, such revenues revert back to the local and regional communities. Why is this so? Lack of consultation and public participation is usually the answer to this question.

One of best Brazilian public consultation experiences regarding natural resources management are those of the River Basins Committees (Comites de Bacias Hidrográficas), which have specific laws and regulations that compel them to share public concerns with stakeholders involved. However, water management is the only natural resource that has such a transparent public consultation policy in Brazil.

In the case of mineral resources, according to DNPM/ MME, the Federal Mining Agency in Brazil, in 2008 the mining companies paid 225 million dollars in royalties to Federal and State Governments, as well to the Municipalities. However, since stakeholder consultations or any other public discussions on how to use these funds are unusual, the mining sites communities rarely know where the money originates and how or where it is going to be spent. Most mining communities are not organized nor do they have civil organizations to support requests or needs. Moreover, most of them are not yet aware of the sustainable development (SD) concepts or goals that should drive their present and future choices.

As a contribution, the authors have developed and applied a guide to evaluate SD concerns and aspects regarding small mining operations sites (small mining clusters). See www.cetem.gov.br/publicacao/cetem_sed_ 75.pdf. In addition, some mining companies are aware of this challenge and are proposing their own guidelines in regions where they conduct business.

See, for instance, ICMM at www.csrwire.com/ News/9025.html or Anglo's SEAT protocol at www. angloamerican.co.uk/aa/development/society/engagement/ seat/ and Newmont's www.beyondthemine.com/2007/ $? 1=2 \&$ pid $=240 \&$ parent $=253 \& \mathrm{id}=296$. We suggest that the "River Basins Committees" concept that works well in many countries might be seen as a useful example and could be applied to support natural resources public management.

Carlos C. Peiter and Roberto C. Villas Boas Researchers at the Centro de Tecnologia Mineral, CETEM Rio de Janeiro, Brazil 